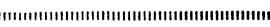

Original Article

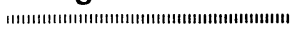

\section{Biological Properties of Fungitoxic Propargyl $N$-(6-ethyl-5-iodo-2-pyridyl)carbamate}

\author{
Shigeru Mitani, Kanako Nakano,* Norifusa Matsuo,* \\ and Terumasa KomyojI \\ Agrochemicals Development Laboratory, and *Organic Chemistry Research Laboratory, \\ Central Research Institute, Ishihara Sangyo Kaisha, Ltd., \\ Nishishibukawa, Kusatsu 525, Japan
}

(Received September 28, 1994; Accepted February 2, 1995)

\begin{abstract}
Propargyl N-(6-ethyl-5-iodo-2-pyridyl)carbamate (PEIP) exhibited high fungitoxic activities against Erysiphe graminis f. sp. tritici, Sclerotinia sclerotiorum, Botrytis cinerea, Pyricularia oryzae, and Rhizoctonia solani at $0.1 \mathrm{ppm}$ in vitro and 8 to $63 \mathrm{ppm}$ in vivo. It also showed activity against benzimidazole-resistant isolates of $B$. cinerea as well as the sensitive isolates. PEIP possessed not only preventive activity, but also curative activity and translaminar action. The excellent activity of PEIP against $B$. cinerea and Elsinoe ampelina was also confirmed in field trials. PEIP induced morphological changes in the conidial germination and nuclear arrangement in germ-tubes of $B$. cinerea in a similar manner to that of benomyl, a benzimidazole fungicide. These results suggest that PEIP interferes with the cell division of this fungus.
\end{abstract}

\section{INTRODUCTION}

The benzimidazole resistance of plant pathogenic fungi has increased throughout the world, making it difficult to control many diseases with this class of fungicides. ${ }^{1)}$ As a strategy to cope with the fungicide resistance of plant pathogens, the $N$-phenylcarbamate diethofencarb, which shows negatively correlated cross-resistance to resistant strains, has been introduced for practical use. But increased sensitivity to diethofencarb was limited to isolates with only high levels of benzimidazole resistance. ${ }^{2)}$

We discovered a family of pyridylcarbamate had high potency for the control of benzimidazole-resistant and -sensitive isolates of cucumber gray mold (Botrytis cinerea). ${ }^{3)}$ Among the compounds of this family, propargyl $N$-(6-ethyl-5-iodo-2-pyridyl)carbamate (PEIP) as shown in Fig. 1 had the most potent activity against both isolates. Moreover the compound had a cell division inhibitory activity similar to benzimidazoles and dietho- fencarb. The excellent activity and interesting characteristic of this new compound encouraged us in further studies to know its biological properties.

The present paper describes some biological properties of PEIP including the fungicidal spectrum in vitro and the disease control efficacy due to the preventive, curative and systemic activities in field trials as well as pot tests. We also examined the mode of action of PEIP by using microscopic observation.

\section{MATERIALS AND METHODS}

\section{Chemicals and Formulations}

PEIP and diethofencarb were synthesized according to previously described methods, ${ }^{4,5)}$ and the structures of the compounds were confirmed by IR, Mass and ${ }^{1} \mathrm{H}$ NMR spectrometry.

The benzimidazole fungicide benomyl $(50 \%$ wettable powder) and the $4^{\prime}, 6$-diamidino-2phenylindole (DAPI, Wako Chemical Industries, Ltd.) were purchased.

PEIP and diethofencarb were further 


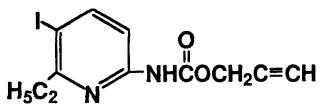

Fig. 1 PEIP, propargyl $N$-(6-ethyl-5-iodo-2pyridyl) carbamate.

formulated as $20 \%$ wettable powders as described before. ${ }^{4)}$

\section{Plants and Pathogens}

In glasshouse tests, cucumber (cv. Suyo), tomato (cv. Ponderosa), rice (cv. Koshihikari), wheat (cv. Norin No. 61) and oat (cv. Zenshin) seedlings were grown in a polyethylene pot (diameter: $7.5 \mathrm{~cm}$ ). In case of cucumber plants, the experiments were performed with plants of one or two true leaf stage. Tomato, rice and oat plants were used at four to six leaf stage.

All the pathogens stored in the fungal bank of our company were used for in vitro and/or in vivo tests. We employed five kinds of $B$. cinerea isolate, which are highly resistant to benzimidazole (HR, S, S), to both of benzimidazole and dicarboximide (HR, R, S), to diethofencarb $(\mathrm{S}, \mathrm{S}, \mathrm{R})$, to both of dicarboximide and diethofencarb $(\mathrm{S}, \mathrm{R}, \mathrm{R})$, and intermediately resistant to benzimidazole and highly to diethofencarb (IR, S, R). B. cinerea (IR, S, R) was kindly gifted by Agricultural Technical Center of National Federation of Agricultural Co-operative Association (ZenNoh).

\section{Fungicidal Spectrum in vitro}

To examine the antifungal spectrum in vitro of PEIP, we employed an agar dilution method. Each isolate was cultured on potatosucrose agar (PSA) at 20 to $25^{\circ} \mathrm{C}$. Mycelial disks (diameter: $4 \mathrm{~mm}$ ) were then cut from the margins of the colonies and placed on the PSA plates containing PEIP in various concentrations. After incubation at their optimum temperature for an optimum period, colony diameter on PSA medium was measured to calculate $\mathrm{EC}_{90}$ value.

\section{Fungicidal Spectrum in vivo}

To evaluate the preventive activity in the glasshouse, $10 \mathrm{ml}$ of solution containing PEIP was sprayed over the plant using a spray gun $24 \mathrm{hr}$ before inoculation. The test plants were inoculated either by spraying aqueous spore suspensions (Phytophthora infestans, Pseudoperonospora cubensis, Colletotrichum lagenarium, Cochliobolus miyabeanus and Pyricularia oryzae) or by dusting the spores on the leaves (Erysiphe graminis, Sphaerotheca fuliginea and Puccinia coronata). Otherwise, mycelial disks of $4 \mathrm{~mm}$ in diameter were placed on the detached cucumber leaf (Sclerotinia sclerotiorum and $B$. cinerea), or the rice straws previously incubated with the sheath blight pathogen (Rhizoctonia solani) were used to inoculate between leaf sheath portions. The inoculated plants were incubated in the glasshouse for 3 to 11 days at 20 to $28^{\circ} \mathrm{C}$.

To assess fungicidal activity, degree of disease development was observed visually and evaluated according to the following indices:

5: No lesion

4: Lesion area under $5 \%$ of treated leaves

3: Lesion area under $10 \%$ of treated leaves

2: Lesion area under $50 \%$ of treated leaves

1: Lesion area under $70 \%$ of treated leaves

0: Lesion area over $70 \%$ of treated leaves

With indices 5 to 3 , the test compound was judged to be effective, and the minimum effective concentration (MEC) was determined.

\section{Curative and Systemic Activity}

The curative activity of PEIP for $C$. lagenarium was evaluated in the same manner as described in the preventive activity, except plants were inoculated 24 or $48 \mathrm{hr}$ before the treatment. In this experiment, cucumber plants (the first true leaf) were inoculated with spore suspension of $C$. lagenarium. The inoculated plants were incubated in the glasshouse for 5 days.

In $B$. cinerea, we employed cucumber cotyledons and a paper disk method ${ }^{6)}$ with some modifications. Spore suspension in potato-sucrose broth (PSB) was dropped on a paper disk which was previously placed on the 
detached cucumber leaf (the first true leaf). After incubating for $24 \mathrm{hr}$ in a moist plastic case at $20^{\circ} \mathrm{C}$, a leaf with the lesion was dipped into a PEIP aqueous solution for a minute, and incubated in a moist plastic case for 3 days.

Systemic activity from root to leaf was evaluated by pouring $20 \mathrm{ml}$ of solution on the soil surface around the cucumber plant $48 \mathrm{hr}$ before inoculation. Translaminar activity from leaf-upper-surface to leaf-under-surface was also evaluated. Chemical solution was sprayed on the upper-surface of the cucumber leaf $24 \mathrm{hr}$ before inoculation. Mycelial disks of $B$. cinerea were inoculated on the undersurface of the detached leaf which had been sprayed on the upper side. The inoculated leaves were incubated in a moist plastic case for 3 days.

Except for the test of curative application against $B$. cinerea, the disease severity of cucumber plants was rated in a similar manner above. In the test of curative activity of $B$. cinerea, percentage of disease development was calculated by measuring the diameter of each lesion just before the chemical application (a day after inoculation) and at the end of the experiment (3 days after inoculation). Degree of disease development was evaluated according to the following indices:

5: No development

4: Lesion development under $5 \%$ of control leaves

3: Lesion development under $10 \%$ of control leaves

2: Lesion development under $50 \%$ of control leaves

1: Lesion development under $70 \%$ of control leaves

0: Lesion development over $70 \%$ of control leaves

\section{Field Trials}

PEIP was tested at the concentration of 250 and $500 \mathrm{ppm}$ by a foliar spray at $1000 \mathrm{l} / \mathrm{ha}$ for the control of $B$. cinerea (curative activity) on kidney bean (cv. Himetebou) at an earlier stage of disease development and of 1000 ppm by a dormant-period treatment for Elsinoe ampelina (preventive activity) on grape (cv. Neomuscut). Trials were laid down as randomized blocks, and replicated twice with 12 plants/plot for kidney bean or with 5 to 6 trees/plot for grape under natural infection. Disease development was observed 6 days after PEIP treatment $(B$. cinerea) or 27 days after treatment (E. ampelina). Percent of diseased plants or leaves (PDP or PDL) was determined by counting the number of diseased plants (kidney bean) or leaves (grape), and calculated by the following formula:

$$
\begin{aligned}
\mathrm{PDP} \text { or } \mathrm{PDL}= & \text { number of diseased plants } \\
& \text { or leaves/total number of } \\
& \text { plants or leaves } \times 100
\end{aligned}
$$

\section{Observation of Spore Germination}

A suspension of conidia of $B$. cinerea containing $10 \%$ PSB was mixed with each test compound at a final concentration of $1 \mathrm{ppm}$, and incubated at $20^{\circ} \mathrm{C}$ for $24 \mathrm{hr}$ on a glass slide. Germination of conidia was observed by light microscopy (OLYMPUS BH-2 microscope).

\section{Observation of Nuclei}

Conidia of $B$. cinerea were suspended in sterile distilled water containing $10 \%$ PSB medium. After germination, each test compound was added, and $15 \mu \mathrm{l}$ of the suspension was spread and incubated on the glass slide at $20^{\circ} \mathrm{C}$ for $24 \mathrm{hr}$. The suspension was air dried and stained with DAPI of $0.25 \mathrm{ppm}$ in methanol solution. The stained preparations were observed under a fluorescence microscope (OLYMPUS AHBT-FL-2) with HBO 200 W/2 light source. One excitation filter (UG-1, $365 / 10$ ), one dichroic mirror (DM-400) and barrier filter (L420) were used.

\section{RESULTS}

\section{Fungitoxic Spectrum}

The fungitoxic activities of PEIP in vitro and in vivo (preventive activity) are summarized in Table 1. PEIP possessed a broad spectrum of activities against Ascomycetes, Basidiomycetes and Deuteromycetes with some exceptions and had a slight activity against Oomycetes.

It showed an especially high activity against Monilinia fructicola, S. sclerotiorum, Ustilago nuda, B. cinerea, Cercospora beticola, Cercospora 
Table 1 Biological activity of PEIP in laboratory (in vitro) and glasshouse (in vivo) tests.

\begin{tabular}{|c|c|c|}
\hline \multirow{2}{*}{ Pathogen } & \multicolumn{2}{|c|}{$\begin{array}{l}\text { Minimum effective } \\
\text { concentration (ppm) }\end{array}$} \\
\hline & In vitro ${ }^{a)}$ & Invivo ${ }^{\mathrm{b})}$ \\
\hline \multicolumn{3}{|l|}{ Phycomycetes } \\
\hline Aphanomyces cochlioides & $>100$ & - \\
\hline Phytophthora infestans & $>100$ & $>500$ \\
\hline Pseudoperonospora cubensis & - & 500 \\
\hline Pythium aphanidermatum & $>100$ & - \\
\hline \multicolumn{3}{|l|}{ Ascomycetes } \\
\hline Cochliobolus miyabeanus & $>100$ & $>500$ \\
\hline Colletotrichum lagenarium & 1 & 31 \\
\hline Elsinoe ampelina & 1 & - \\
\hline Erysiphe graminis f. sp. tritici & - & 8 \\
\hline Monilinia fructicola & $<0.1$ & - \\
\hline Mycosphaevella melonis & 1 & -- \\
\hline Pyrenophora graminea & 1 & - \\
\hline Rosellinia necatrix & 1 & - \\
\hline Sclerotinia sclerotiorum & $<0.1$ & 31 \\
\hline Sphaerotheca fuliginea & - & 250 \\
\hline Valsa ceratosperma & 1 & - \\
\hline Venturia nashicola & 1 & - \\
\hline \multicolumn{3}{|l|}{ Basidiomycetes } \\
\hline Corticium rolfsii & 10 & 一 \\
\hline Helicobasidium mompa & 10 & - \\
\hline Puccinia coronata & - & 500 \\
\hline Ustilago nuda & $<0.1$ & - \\
\hline \multicolumn{3}{|l|}{ Deuteromycetes } \\
\hline $\begin{array}{l}\text { Alternaria alternata } \\
\text { apple pathotype }\end{array}$ & 10 & - \\
\hline Botrytis cinerea $(\mathrm{HR}, \mathrm{S}, \mathrm{S})^{\mathrm{c}}{ }^{2}$ & $<0.1$ & 16 \\
\hline Botrytis cinerea $(\mathrm{HR}, \mathrm{R}, \mathrm{S})$ & $<0.1$ & 16 \\
\hline Botrytis cinerea $(\mathrm{S}, \mathrm{S}, \mathrm{R})$ & $<0.1$ & 16 \\
\hline Botrytis cinerea $(\mathrm{S}, \mathrm{R}, \mathrm{R})$ & $<0.1$ & 16 \\
\hline Botrytis cinerea (IR, $\mathrm{S}, \mathrm{R})$ & 0.1 & 63 \\
\hline Cercospora beticola & $<0.1$ & - \\
\hline Cercospora kikuchii & $<0.1$ & - \\
\hline Cladosporium fulvum & 1 & - \\
\hline $\begin{array}{l}\text { Fusarium oxysporum f. sp. } \\
\text { raphani }\end{array}$ & 1 & - \\
\hline Helminthosporium sacchari & $>100$ & - \\
\hline Pyricularia oryzae & $<0.1$ & 31 \\
\hline Rhizoctonia solani & $<0.1$ & 63 \\
\hline Rhynchosporium secalis & 10 & - \\
\hline Verticillium dahliae & 1 & - \\
\hline
\end{tabular}

a) Agar dilution method, $\mathrm{EC}_{90}$ value.

b) Pot tests (preventive activity), $\mathrm{EC}_{90}$ value.

c) Highly resistant to benzimidazoles $(\mathrm{HR}, \mathrm{S}, \mathrm{S})$, to both of benzimidazoles and dicarboximides (HR, R, S), to diethofencarb (S, S, R), to both of dicarboximides and diethofencarb $(S, R, R)$, and intermediately resistant to benzimidazoles and highly to diethofencarb (IR, S, R). kikuchii, $P$. oryzae and $R$. solani at $0.1 \mathrm{ppm}$ in vitro. PEIP had a similar degree of antifungal activity against (HR,S,S), (HR, R,S), (S,S,R) and $(\mathrm{S}, \mathrm{R}, \mathrm{R})$ isolates of $B$. cinerea. Although PEIP showed activity against (IR,S, R) isolate, it was somewhat less sensitive than the other isolates. PEIP was also active against $C$. lagenarium, E. ampelina, Mycosphaerella melonis, Pyrenophora graminea, Rosellinia necatrix, Valsa ceratosperma, Venturia nashicola, Cladosporium fulvum, Fusarium oxysporum, and Verticillium dahliae in vitro at $1 \mathrm{ppm}$. On the other hand, an antifungal activity against Aphanomyces cochlioides, Phytophthora infestans, Pythium aphanidermatum, Cochliobolus miyabeanus and Helminthosporium sacchari was not observed even at $100 \mathrm{ppm}$.

In pot tests, PEIP was highly fungitoxic to E. graminis f. sp. tritici (MEC: $8 \mathrm{ppm}$ ), $B$. cinerea (MEC: $16 \mathrm{ppm}$ against (HR,S,S), (HR, R,S), (S,S,R), and (S,R,R) isolates and 63 ppm against (IR,S,R) isolate), C. lagenarium (MEC: $31 \mathrm{ppm}$ ), S. sclerotiorum (MEC: 31 $\mathrm{ppm}), P$. oryzae (MEC: $31 \mathrm{ppm})$, and $R$. solani (MEC: $63 \mathrm{ppm}$ ). Against $P$. infestans and $C$. miyabeanus, the control effects were not observed in vivo at $500 \mathrm{ppm}$.

\section{Curative and Systemic Activity}

PEIP possessed not only a preventive activity, but also a curative activity against $B$. cinerea and $C$. lagenarium on cucumber plants (Table 2). When the plants were sprayed 24 or $48 \mathrm{hr}$ after inoculation at $125 \mathrm{ppm}$, disease development caused by $C$. lagenarium was

Table 2 Curative activitya) of PEIP against Botrytis cinerea and Colletotrichum lagenarium on cucumber plants.

\begin{tabular}{cccc}
\hline & \multicolumn{3}{c}{ Treatment time after inoculation } \\
\cline { 2 - 4 }$(\mathrm{PEIP})$ & B. cinerea $(\mathrm{S}, \mathrm{S}, \mathrm{R})^{\mathrm{b})}$ & \multicolumn{2}{c}{ C. lagenarium } \\
\cline { 2 - 4 } & $24 \mathrm{hr}$ & $24 \mathrm{hr}$ & $48 \mathrm{hr}$ \\
\hline 500 & 4 & 5 & 5 \\
125 & 1 & 5 & 5 \\
31 & 0 & 1 & 0 \\
\hline
\end{tabular}

a) With indices 5 to 3 , the test compound was judged to be effective.

b) Sensitive to benzimidazoles and dicarboximides, highly resistant to diethofencarb. 
Table 3 Systemic activity of PEIP against Botrytis cinerea on cucumber plants.

\begin{tabular}{ccc}
\hline PEIP (ppm) & $\begin{array}{c}\text { Roots } \\
\text { to leaves }\end{array}$ & $\begin{array}{c}\text { Leaf-upper-surface } \\
\text { to leaf-under-surface }\end{array}$ \\
\hline 1000 & 1 & 5 \\
500 & 0 & 5 \\
125 & - & 1 \\
\hline
\end{tabular}

With indices 5 to 3 , the test compound was judged to be effective.

controlled perfectly. Good activity against $B$. cinerea was also observed at $500 \mathrm{ppm}$, however disease control was inferior to that against $C$. lagenarium.

Translaminar activity from leaf-upper-surface to leaf-under-surface and systemic activity from root to leaf were examined as shown in Table 3. Leaf-upper-surface treatment of PEIP gave complete control of $B$. cinerea at 500 and $1000 \mathrm{ppm}$. On the other hand, soil application of PEIP solution around the cucumber seedling did not show efficacy against $B$. cinerea at $1000 \mathrm{ppm}$.

\section{Field Trials}

Field trials revealed a good curative activity of PEIP against $B$. cinerea on kidney bean at 250 or $500 \mathrm{ppm}$ (Fig. 2). When the solution of PEIP was applied for grape in a

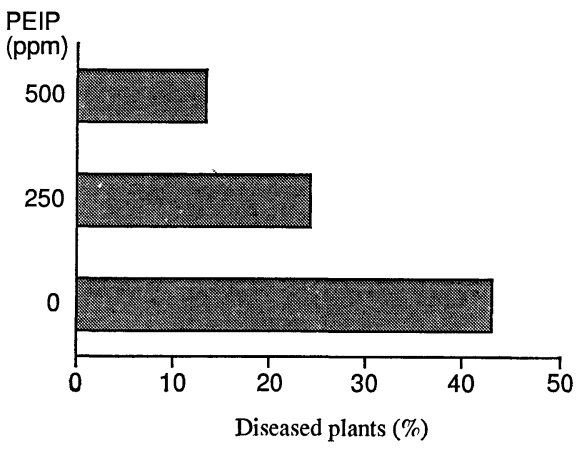

Fig. 2 Control efficacy of PEIP against Botrytis cinerea on kidney bean in field trials.

Trial was laid down as replicated 2 times with 12 plants/plot under natural infection. PEIP treatment was done at the earlier stage of disease development. Six days after treatment, percent of diseased plants was determined by counting the number of diseased plants.

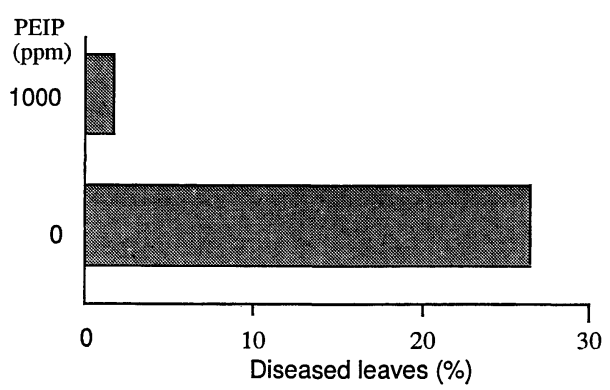

Fig. 3 Control efficacy of PEIP against Elsinoe ampelina on grape in field trials.

Trial was laid down as replicated 2 times with 5 to 6 trees/plot under natural infection. PEIP treatment was done at dormant period of plants. Twenty-seven days after treatment, percent of diseased leaves was determined by counting the number of diseased leaves.

dormant period, excellent control of $E$. ampelina was observed at 1000 ppm (Fig. 3).

\section{Effect of PEIP on Germination}

Influence of PEIP on germination of conidia of $B$. cinerea was observed under a microscofe (Fig. 4). Although PEIP did not inhibit the spore germination, it induced morphological abnormalities such as swollen and distorted hyphal branching in both isolates of $(\mathrm{S}, \mathrm{S}, \mathrm{R})$ and $(\mathrm{HR}, \mathrm{R}, \mathrm{S})$ as shown in Fig. $4 \mathrm{~A}$ and $4 \mathrm{E}$. These morphological changes were quite similar to those of benomyl against isolate of $(\mathrm{S}, \mathrm{S}, \mathrm{R})$ (Fig. 4B) and those of diethofencarb against (HR,R,S) (Fig. 4G).

\section{Effect of PEIP on Nuclei}

The treatment of germinating conidia of $B$. cinerea with $1 \mathrm{ppm}$ of PEIP induced the formation of abnormal shape of nuclei in the isolates of (S,S,R) and (HR,R,S) (Fig. 5A and 5E). Quite similar phenomena were also observed in the treatment with benomyl on isolate of $(\mathrm{S}, \mathrm{S}, \mathrm{R})$ (Fig. 5B) and with diethofencarb against (HR,R,S) (Fig. 5G).

\section{DISCUSSION}

Although the benzimidazole fungicides contributed to disease protection of broad varieties of important crops, emergence of resistance to this class of fungicides made it difficult to control many diseases. ${ }^{1)}$ As a strategy to 
cope with this resistance, the mixture of benzimidazole, carbendazim and diethofencarb was introduced. But applications of the mixture resulted in selective effect on a population, so

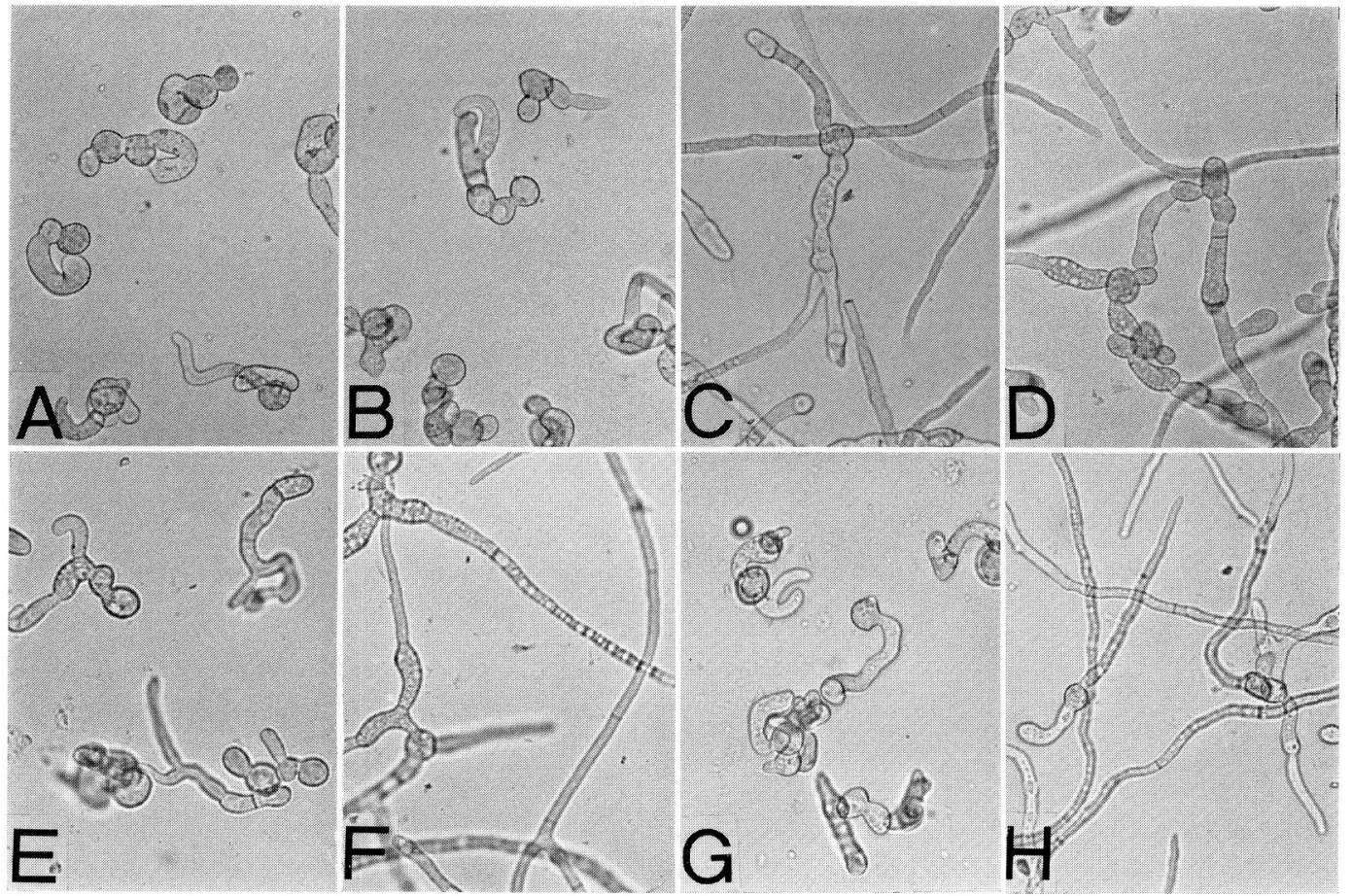

Fig. 4

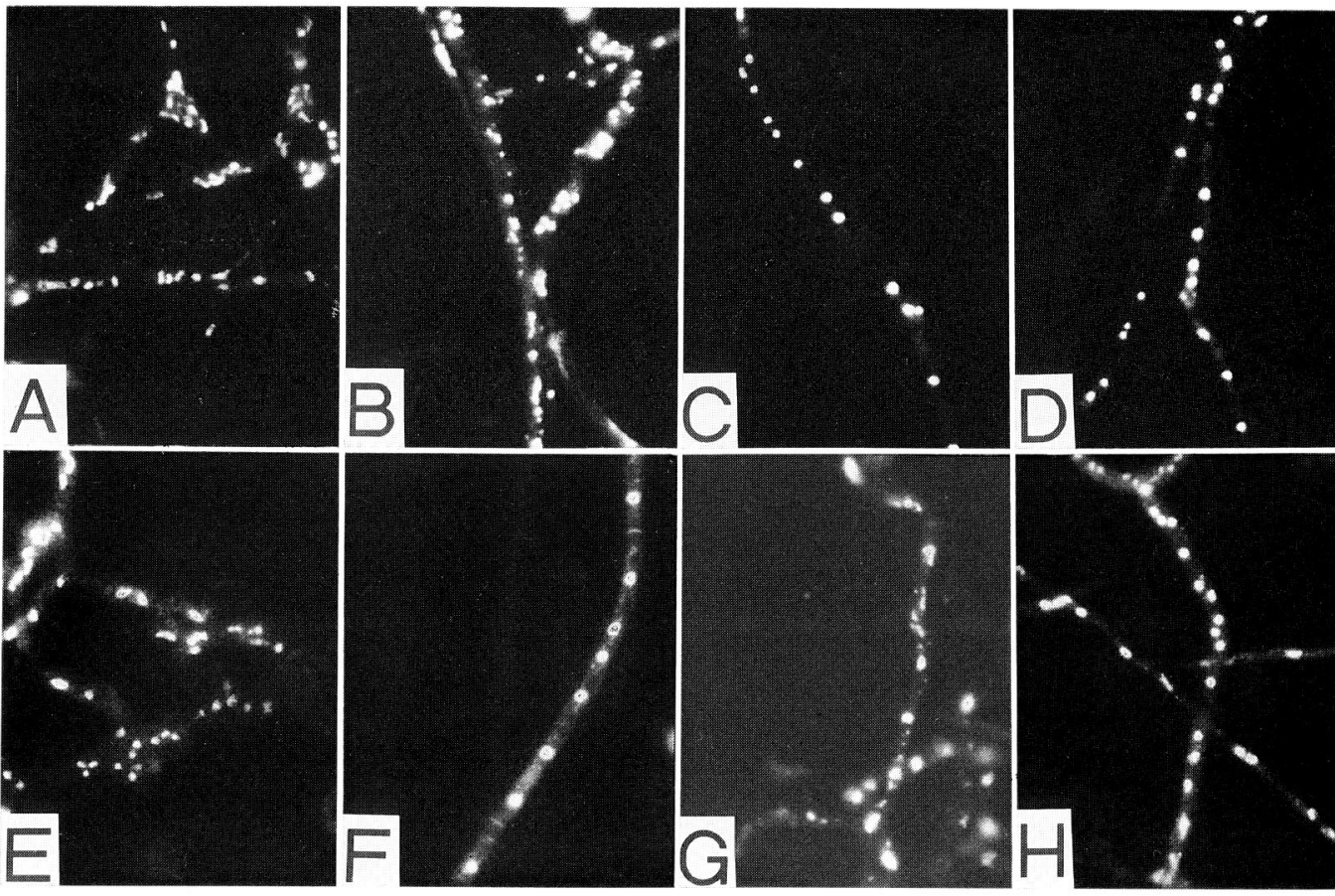


that intermediate or weak benzimidazole resistant strains predominated in the fields. ${ }^{2)}$ Thus unsatisfactory control of the mixture was observed where the fungal population was dominated by the strains resistant to the mixture. Therefore the development of new chemicals for controlling both sensitive and resistant isolates has been needed. PEIP had a high activity against $B$. cinerea regardless of the level of benzimidazole resistance, suggesting that this compound has a high potency for the control of plant pathogens to cope with benzimidazole-resistance.

PEIP possessed not only a preventive activity, but also a curative activity against $B$. cinerea and $C$. lagenarium on cucumber plants. Systemic activity from leaf-upper-surface to leaf-under-surface was also observed. These curative and systemic properties are important for leading to the excellent control of the diseases in the fields.

Furthermore, phytotoxicity on varieties of crops, e.g. cucumber, tomato, kidney bean, rice, oat and grape was not observed at all when PEIP was treated at $500 \mathrm{ppm}$ (data not shown). These results suggest that PEIP has a high potency to be a new fungicide for practical use.

Many systemic fungicides including benzimidazoles, ${ }^{7,8)} \quad \mathrm{N}$-phenylcarbamates, ${ }^{9,10)} \mathrm{N}$ phenylformamidoximes, ${ }^{11)}$ dicarboximides ${ }^{12}$ and ergosterol biosynthesis inhibitors (EBIs) ${ }^{13}$ ) are known to induce morphological change in fungi. Among them the primary mode of action of benzimidazoles is generally considered to inhibit microtubule assembly by binding to beta-tubulin. ${ }^{14,15)} \quad \mathrm{N}$-Phenylcarbamates, $\mathrm{N}$ phenylformamidoximes and a new series of compounds, $N$-phenylanilines exhibit similar biological properties to those of benzimidazoles.
These groups of compound show specific an antifungal activity against highly benzimidazole-resistant strains, ${ }^{16-18)}$ and induced distorted and swollen-germ tubes of sensitive strains of $B$. cinerea. $^{9-11}$ In $B$. cinerea, mitosis appeared to be arrestment after the treatments with $\mathrm{N}$-phenylcarbamates, diethofencarb and methyl $N$-(3,5-dichlorophenyl)carbamate (MDPC). ${ }^{9,10)}$ In Venturia nashicola, disordered configuration of nuclei in germinated conidia of sensitive strains was also observed by the treatment with a $N$-phenylformamidoxime, $N$-(3,5-dichloro-4-propynyloxyphenyl)- $N^{\prime}$-methoxyformamidine(DCPF) ${ }^{19)}$ Recently, Fujimura et al. reported that selective fungitoxicity of diethofencarb to a benzimidazole-resistant strain was by binding of the compounds to tubulin in Neurospora crassa. ${ }^{20,21}$

PEIP was similar to benomyl and diethofencarb in having morphological effects on conidial germination and nuclear arrangement in germ-tubes. These results suggest that PEIP is most likely to inhibit cell division of the target fungus, $B$. cinerea. Pyridylcarbamates including PEIP might interfere with the formation or functions of microtubule in a manner similar to that of benzimidazoles, $\mathrm{N}$ phenylcarbamates, $N$-phenylformamidoximes and/or $N$-phenylanilines. It should be emphasized that PEIP, benomyl and diethofencarb all belong to aromatic carbamates. Moreover PEIP had a similar pattern in the fungicidal spectrum to benzimidazoles, which is well known to have wide fungicidal spectrum. These fungicides were highly active on most Ascomycetes and Deuteromycetes, whereas they were less active on the Bastdiomycetes and inactive on the Oomycetes. ${ }^{7,8)}$

If the fungicidal activities of PEIP were due to its binding to tubulin, the active sites of

Fig. 4 Light photomicrographs of germianted conidia of Botrytis cinerea of (S, S, R) isolate (A, $\mathrm{B}, \mathrm{C}$ and $\mathrm{D})$ and $(\mathrm{HR}, \mathrm{R}, \mathrm{S})$ isolate $(\mathrm{E}, \mathrm{F}, \mathrm{G}$ and $\mathrm{H})(\times 280)$.

Conidia were incubated in the absence and the presence of $1 \mathrm{ppm}$ of test compounds. A and $\mathrm{E}$ : treated with PEIP, B and F: treated with benomyl, C and G: treated with diethofencarb, $\mathrm{D}$ and $\mathrm{H}$ : control.

Fig. 5 Fluorescence photomicrographs of germinated conidia of Botrytis cinerea of (S, S, R) isolate $(\mathrm{A}, \mathrm{B}, \mathrm{C}$ and $\mathrm{D})$ and $(\mathrm{HR}, \mathrm{R}, \mathrm{S})$ isolate $(\mathrm{E}, \mathrm{F}, \mathrm{G}$ and $\mathrm{H})(\times 580)$.

Conidia were incubated in the absence and the presence of $1 \mathrm{ppm}$ of test compounds. A and E: treated with PEIP, B and F: treated with benomyl, C and G: treated with diethofencarb, $\mathrm{D}$ and $\mathrm{H}$ : control. 
PEIP or of the target protein might be different from the other compounds as reported in the case of rhizoxin. The macrolide compound rhizoxin, which has a cell division inhibition activity, inhibited mycelial growth of $B$. cinerea and other fungi. ${ }^{22,23)}$ Rhizoxin was bound to beta-tubulin, but the binding site differed from benzimidazoles. ${ }^{24)}$ Although the binding sites of PEIP was not clarified yet, PEIP would be the first aromatic carbamate which may have a cell division inhibition activity against both benzimidazole-sensitive and -resistant isolates.

\section{ACKNOWLEDGMENTS}

We wish to express our thanks to Dr. H. Ishii of Fruit Tree Research Station for his invaluable suggestions.

\section{REFERENCES}

1) C. J. Delp: Plant Dis. 7, 652 (1980)

2) Y. Elad, H. Yunis \& T. Katan: Plant Pathol. 41, 41 (1992)

3) T. Akagi, S. Mitani, K. Ito, I. Shigehara \& T. Komyoji: Abstr.; 8th Int. Congr. Pestic Chem., Washington, D.C., U.S.A., p. 884, 1994

4) I. Shigehara, T. Komyoji, T. Nakajima, K. Ito \& S. Mitani (Ishihara Sangyo Kaisha, Ltd.): Eur. Pat. Appl. EP 0430127 (1991)

5) H. Noguchi, T. Kato, J. Takahashi, Y. Ishiguri, S. Yamamoto \& K. Kamoshita (Sumitomo Chemical Co., Ltd.): Jpn. Kokai Tokkyo Koho JP 58-126856 (1983)

6) K. Tanaka \& A. Kiso: Bull. Res. Lab. JPPA 5, 17 (1991)

7) C. J. Delp: “Modern Selective Fungicide," Longman Scientific \& Technical, New York, pp. 233-244, 1987

8) L. C. Davidse: Annu. Rev. Phytopathol. 24, 43 (1986)

9) K. Suzuki, T. Kato, J. Takahashi \& K. Kamoshita: J. Pesticide Sci. 9, 497 (1984)

10) J. Takahashi, S. Nakamura, H. Noguchi, T. Kato \& K. Kamoshita: J. Pesticide Sci. 13, 63 (1988)

11) K. Hayakawa, A. Nakayama, H. Nishikawa, A. Nakata, S. Sano \& C. Yokota: J. Pesticide Sci. 16, 481 (1991)

12) R. P. Davis \& C. Dennis: Pestic. Sci. 12, 521 (1981)

13) A. Kerkenaar \& D. Barug: Pestic. Sci. 15, 199 (1984)

14) L. C. Davidse \& W. Flach: J. Cell. Biol. 72, 174 (1977)
15) J. V. Kilmartin: Biochemistry 20, 3629 (1981)

16) T. Kato, K. Suzuki, J. Takahashi \& K. Kamoshita: J. Pesticide Sci. 9, 489 (1984)

17) A. Nakata, S. Hashimoto, S. Sano \& K. Hayakawa: J. Pesticide Sci. 17, 243 (1992)

18) G. Josepovits, M. Gasztonyi \& G. Mikite: Pestic. Sci. 35, 237 (1992)

19) H. Ishii, M. V. Raak, I. Inoue \& A. Tomikawa: Plant Pathol. 41, 543 (1992)

20) M. Fujimura, T. Kamakura, H. Inoue, S. Inoue \& I. Yamaguchi: Pestic. Biochem. Physiol. 44, 165 (1992)

21) M. Fujimura, T. Kamakura \& I. Yamaguchi: J. Pesticide Sci. 17, 237 (1992)

22) M. Takahashi, S. Iwasaki, H. Kobayashi, S. Okuda, T. Murai \& Y. Sato: Biochim. Biophys. Acta, 926, 215 (1987)

23) H. Ishii: "Target Sites of Fungicide Action," CRC Press, London, pp. 44-52, 1992

24) M. Takahashi, S. Matsumoto, S. Iwasaki \& I. Yahara: Mol. Gen. Genet. 222, 169 (1990)

\section{要 約}

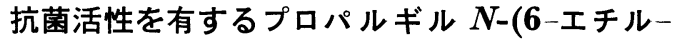
5-ヨード-2-ピリジル) カーバメートの作用 特性

三谷 滋, 中野加奈子 松尾憲総，光明寺輝正

プロパルギル N-(6-エチル-5-ヨード-2-ピリジル)カーバメート (PEIP) は Erysiphe graminis. f. sp. tritici, Sclerotinia sclerotiorum, Botrytis cinerea, Pyricularia oryzae, Rhizoctonia solani 等に高い活性 を示し, その最低有効濃度は寒天平板希釈法で $0.1 \mathrm{ppm}$ 以下であり，ポット試験ではおのおの 8〜63 ppm であ った. また PEIP はベンズイミダゾール感受性のみな らず耐性の B. cinerea にも同様の高い効果を示した。 また B. cinerea および C. lagenarium におのおの 500 および $125 \mathrm{ppm}$ で治療効果を有していた。移行性に関 しては根からの浸透性は 1000 ppm でも認められなか ったが，葉表から葉寒への移行性は 500 ppm で認めら れた。 また B. cinerea および Elsinoe ampelina に対 する効果は固場試験でも確認できた. B. cinerea の分生 胞子発芽や，発芽管中の核に対する PEIP の影響を調 ベたところ，形態に異常が認められた。これらの作用は ベノミルを感受性菌に処理したときのものと酷似してい たことから，PEIP の作用点は有糸分裂阻害である可 能性が示唆された。 